\title{
PENINGKATAN HASIL BELAJAR MATEMATIKA SISWA KELAS XI IPA SMA NEGERI 1 BANGKINANG MELALUI MODEL PEMBELAJARAN KOOPERATIF TIPE STAD
}

\author{
Hendra \\ SMAN 1 Bangkinang, Jl. Bendungan Uwai Bangkinang \\ Email: hendralazim@gmail.com
}

\begin{abstract}
Students of SMAN 1 Bangkinang real condition in the field showed low learning result of mathematics. This was seen from the results of students' study grade XI IPA only $42 \%$ of 28 students. This was based on daily test analysis performed. In general, students of grade XI IPA during mathematics learning have difficulty in understanding abstract material and less active students when studying mathematics. Conventional learning strategies (lectures) often embed less interested students in learning mathematics. Solving of this problem, classroom action research was done by using STAD type cooperative learning model in learning opportunity of an event. Action Research in this class is done 2 cycle learning each cycle consists of four steps are: 1) Planning, 2) Action, 3) Observation, and 4) Reflection. The subjects of this study are students of class XI IPA SMAN 1 Bangkinang Lesson Year 2017/2018. The result of the research was showsn the increase of student learning outcomes through STAD type cooperative learning. Improvement of learning outcomes was characterized by increased absorption and mastery of students' mathematics learning outcomes.
\end{abstract}

Keywords: Mathematics Learning Outcomes, Cooperative Learning Model Type STAD

\begin{abstract}
Abstrak
Siswa SMAN 1 Bangkinang kondisi nyata dilapangan menunjukkan hasil belajar matematika yang rendah. Hal ini dilihat dari hasil belajar siswa kelas XI IPA hanya $42 \%$ dari 28 orang siswa. Hal ini berdasarkan analisa ulangan harian yang dilakukan. Secara umum siswa kelas XI IPA selama pembelajaran matematika mengalami kesulitan dalam memahami materi yang bersifat abstrak serta siswa kurang aktif ketika belajar matematika. Strategi pembelajaran yang bersifat konvesional (ceramah) sering embuat siswa kurang berminat dalam belajar matematika. Untuk mendapatkan solusi dari permasalahan ini maka dilakukan penelitian tindakan kelas dengan menggunakan model pembelajaran kooperatif tipe STAD dalam pembelajaran Peluang Suatu Kejadian. Penelitian Tindakan Kelas ini dilakukan 2 siklus pembelajara masing-masing siklus terdiri dari empat langkah yaitu : 1) Perencanaan, 2) Tindakan, 3) Observasi, dan 4) Refleksi. Subjek penelitian ini adalah siswa kelas XI IPA SMAN 1 Bangkinang Tahun Pelajaran 2017/2018. Hasil penelitian menunjukkan terjadinya peningkatan hasil belajar siswa melalui pembelajaran kooperatif tipe STAD. Peningkatan hasil belajar ditandai dengan peningkatan daya serap dan ketuntasan hasil belajar matematika siswa.
\end{abstract}

Kata Kunci: Hasil Belajar Matematika, Model Pembelajaran Kooperative Tipe STAD

Matematika merupakan salah satu ilmu dasar yang mempunyai peranan penting dalam dunia pendidikan, karena pelajaran matematika merupakan sarana yang dapat digunakan untuk membentuk siswa untuk berfikir secara ilmiah. Di samping itu, pelajaran matematika juga bertujuan utnuk mengembangkan kemampuan berhitung, mengukur dan menggunakan rumus metematika yang diperlukan dalam kehidupan sehari-hari. Oleh karena itu, siswa harus memiliki rasa suka atau tertarik terhadap pelajaran matematika untuk memperoleh hasil belajar yang optimal (Depdiknas 2006)

Tujuan pembelajaran matematika yaitu agar peserta didik memiliki kemampuan: (1) Memahami konsep matematika, menjelaskan keterkaitan antar konsep dan mengaplikasikan konsep atau algoritma secara luwes, akurat, efisien, dan tepat dalam pemecahan masalah; (2) Menggunakan 
penalaran pada pola dan sifat, melakukan manipulasi matematika dalam membuat generalisasi, menyusun bukti, atau menjelaskan gagasan dan pernyataan matematika; (3) Memecahkan masalah yang meliputi kemampuan memahami masalah, merancang model matematika, menyelesaikan model dan menafsirkan solusi yang diperoleh; (4) Mengkomunikasikan gagasan dengan symbol, table, diagram, atau media lain untuk memperjelas keadaan atau masalah; (5) Memiliki sikap menghargai kegunaan matematika dalam kehidupan, yaitu memiliki rasa ingin tahu, perhatian, dan minat dalam mempelajari matematika, serta sikap ulet dan percaya diri dalam pemecahan masalah (Depdiknas 2006)

Berdasarkan tujuan pembelajaran matematika tersebut, dapat disimpulkan bahwa pembelajaran matematika memberi kemampuan pada siswa untuk dapat memahami konsep, menarik kesimpulan, kreatif, mampu menyelesaikan masala, dan mengkomunikasikan gagasan, serta menata cara berfikir dan pembentukan keterampilan matematika untuk mengubah tingkah laku siswa. Perubahan tingkah laku siswa akan terlihat pada akhir proses pembelajaran yang mengacu pada hasil belajar. Hasil belajar dipengaruhi oleh kemampuan siswa dan efektif tidaknya suatu proses pembelajaran (Sudjana, 2000). Salah satu indicator keberhasilan siswa menguasai matematika adalah hasil belajar.Hasil belajar matematika diharapkan adalah hasil belajar matematika yang mencapai ketuntasan belajar matematika.

Berdasarkan pengalaman peneliti sebagai guru matematika SMA Negeri 1 Bangkinang kelas XI IPA kecamatan bangkinang, hasil belajar matematika siswa masih rendah, aktifitas siswa juga masih rendah, adapun KKM yang ditetapkan oleh sekolah adalah 70. Penyebab rendahnya hasil belajar matematika siswa diantaranya adalah faktor guru dan siswa, sarana dan prasarana. Namun dari pengalaman dan pengamatan peneliti sebagai guru, dalam proses pembelajaran guru masih menggunakan model pembelajaran konvesional dengan menggunakan metode ceramah dan Tanya jawab. Model pembelajaran yang masih menjadi pilihan bagi guru adalah metode ceramah dalam menyampaikan materi pelajaran, sehingga siswa cendrung bosan dan kurang bersemangat dalam belajar. Dengan demikian, akan berdampak terhadap rendahnya hasil belajar siswa dan kualitas pembelajaran. Sedangkan metode Tanya jawab merupakan salah satu metode yang kurang efektif, karena tanpa disadari dalam metode ini hanya memberikan kesempatan kepada siswa yang pintar dan aktif yang akan menjawab pertanyaan yang diberikan, sehingga terbentuklah kesenjangan antara siswa yang memiliki kemampuan yang baik/tinggi dengan siswa berkemampuan kurang baik/rendah.

Oleh sebab itu, dapat dikatakan bahwa kualitas hasil belajar siswa sangat dipengaruhi oleh ketepatan dan kemampuan guru dalam memilih dan menggunakan metode pembelajaran. Jika guru dapat memahami proses siswa dalam memperoleh pengetahuan, maka ia dapat menentukan model dan metode pembelajaran yang tepat sehingga tujuan pembelajaran matematika yang dicapai dapat meningkatkan hasil belajar siswa. Sehubungan dengan masalah di atas maka penulis memberikan alternative pemecahan masalah dengan menerapkan model pembelajaran kooperatif tipe STAD. 
Menurut Slavin (1995) tipe STAD adalah suatu tipe pembelajaran kooperatif yang sederhana. Dalam STAD, siswa dibentuk dalam kelompok-kelompok kecil yang beranggotakan 4 atau 5 orang dari berbagai kemampuan, gender dan etnis. Dalam prakteknya guru menyajikan pelajaran dan kemudian siswa belajar dalam kelompok untuk memastikan bahwa setiap anggota kelompok telah menguasai materi. Strategi STAD lebih mementingkan sikap dan proses dari pada prinsip, yaitu sikap dan proses partisipasi dalam rangka mengembangkan potensi kognitif, afektif, dan psikomotor siswa. Pada model pembelajaran kooperatif tipe STAD dalam pemahaman konsep/penggalian informasi pengetahuan dapat dilakukan dalam kelompok kooperatif tipe STAD, hal ini bertujuan agar siswa yang pandai ikut bertanggung jawab membantu siswa yang lemah dalam kelompok masing-masing. Sehingga akan adanya kerja sama yang menguntungkan antara siswa yang memiliki kemampuan tinggi dengan siswa yang memiliki kemampuan sedang dan rendah yaitu siswa yang pandai dapat mengembangkan kemampuan dan keterampilan yang dimiliki dan sebaliknya siswa yang lemah akan terbantu dalam memahami permasalahan yang sedang dibahas. Oleh karena itu kesenjangan antara siswa yang berkemampuan tinggi dan rendah terlihat kerana adanya kerjasama dalam memahami materi yang diajarkan.

Dimyati (1996) mengatakan bahwa belajar merupakan tindakan dari perilaku siswa yang kompleks. Sebagai tindakan, maka belajar hanya dialami oleh siswa itu sendiri, karena siswa adalah penentu terjadinya proses belajar. Slameto (2003) menyatakan bahwa belajar adalah suatu proses usaha yang dilakukan individu untuk memperoleh suatu perubahan tingkah laku secara keseluruhan, sebagai hasi pengalaman individu itu sendiri dalam berinteraksi dengan lingkungannya. Sedangkan Hudoyo (1979) mengatakan bahwa belajar merupakan suatu proses aktif dalam memperoleh pengalaman-pengalaman baru sehingga menyebabkan perobahan tingkah laku. Dan menurut Sudjana (2009) hasil belajar adalah prestasi belajar siswa secara keseluruhan yang menjadi indicator kompetenasi dan derajat perubahan perilaku yang bersangkutan. Kompetensi yang dikuasai siswa perlu dinyatakan sedemikian rupa sehingga dapat dinilai sebagai wujud hasil belajar siswa yang mengacu pada pengalaman langsung.

Menurut Keller (dalam M. Taufik: 2012) hasil belajar adalah prestasi aktan yang ditampilkan oleh anak, sedangkan usaha adalah perubahan yang terarah pada penyelesaian tugas-tugas belajar. Ini berarti bahwa besarnya usaha adalah indicator dari adanya motivasi sedangkan hasil belajar dipengaruhi oleh besarnya usaha yang dilakukan oleh peserta didik. Sedangkan Hamalik (2006) mengemukakan bahwa hasil-hasil belajar adalah pola-pola perubahan nilai-nilai, pengertianpengertian, sikap-sikap,apresiasi, bilitas, dan keterampilan.

Berdasarkan urain di atas dapat disimpulkan bahwa hasil belajar matematika adalah tingkat penguasaan peserta didik terhadap pelajaran matematika setelah memperoleh pengalaman atau proses pembelajaran dalam kurun waktu tertentu yang akan diperlihatkan dengan menyelesaikan soal-soal sesuai dengan materi yang telah dipelajari dengan penilaian tertentu sebagai alat ukur keberhasilan. 
Strategi pembelajaran secara umum dapat diartikan sebagai suatu garis-garis besar haluan untuk bertindak dalam usaha mencapai sasaran yang telah ditentukan. Menurut Sanjaya (dalam Eka Elprida) dalam dunia pendidikan strategi diartikan sebagai perencanaan yang berisi tentang rangkaian kegiatan yang didesain untuk mencapai tujuan pendidikan tertentu. Sedangkan Kemp (dalam Eka Elprida) menjelaskan bahwa strategi pembelajaran adalah suatu kegiatan pembelajaran yang harus dikerjakan guru dan siswa agan tujuan pembelajaran dapat dicapai secara efektif dan efisien.

Sanjaya (dalam Eka) mengatakan ada beberapa strategi pembelajaran yang harus dilakukan oleh seorang guru. 1). Strategi pembelajaran ekspositiri, 2) strategi pembelajaran inquiry, 3) strategi pembelajaran berbasis masalah, dan 4) strategi pembelajaran peningkatan kemampuan berpikir.

Strategi pembelajaran peningkatan kemampuan berpikir merupakan strategi pembelajaran yang menekankan kepada kemampuan berpikir siswa. Dalam strategi pembelajaran ini materi pembelajaran tidak disajikan begitu saja kepada siswa, akan tetapi siswa dibimbing untuk proses menemukan sendiri konsep yang harus dikuasai melalui proses dialogis yang terus menerus dengan memanfaatkan pengalaman siswa. Dengan kata lain model pembelajaran peningkatan kemampuan berpikir adalah model pembelajaran yang bertumpu kepada pengembangan kemampuan berpikir siswa melalui telaahan fakta-fakta atau pengalaman anak sebagai bahan untuk memecahkan masalah yang diajarkan.

Dalam kegiatan pembelajaran guru guru dituntut memiliki kemampuan memilih pendekatan pembelajaran yang tepat. Kemampuan tersebut sebagai sarana dan usaha dalam memilih dan menemukan pendekatan pembelajaran untuk menyajikan materi pembelajaran yang tepat dan sesuai dengan program pembelajaran. Untuk menentukan atau memilih metode pembelajaran hendaknya berangkat dari perumusan tujuan yang jelas. Setelah tujuan pembelajaran ditentukan, kemudian memilih metode pembelajaran yang dipandang efisien dan efektif. Suatu pendekatan pembelajaran dikatakan efisien dan efektif apabila metode tersebut dapat mencapai tujuan pembelajaran dengan waktu yang lebih singkat dari pendekatan lain.

Kriteria lain yang perlu diperhatikan dalam memilih pendekatan pembelajaran adalah tingkat keterlibatan siswa dalam proses pembelajaran. Pendekatan pembelajaran berarti bagaimana menata potensi dan sumber belajar agar program yang sudah dirancang dapat dimanfaatkan secara optimal. Dari beberapa fakta di atas dapat dirumuskan bahwa pendekatan pembelajaran adalah suatu cara yang dipilih guru dalam mengelola kegiatan pembelajaran secara sistematis untuk mrncapai tujuan yang sudah ditetapkan.

\section{METODE}

Model pembelajaran kelompok adalah rangkaian kegiatan belajar yang dilakukan oleh siswa dalam kelompok-kelompok tertentu untuk mencapai tujuan pembelajaran yang telah dirumuskan. Ada empat unsur penting dalam strategi pembelajaran kooperatif, yaitu: 1) adanya peserta dalam 
kelompok, 2) adanya aturan kelompok, 3) adanya upaya belajaranya tiap kelompok, dan 4) adanya tujuan yang hendak dicapai dalam kelompok belajar.

Hasan (dalam Solihatin, 2007) menyatakan cooperative mengandung pengertian bekerjasama dalam mencapai tujuan bersama. Dalam kegiatan kooperatif, siswa secara individu mencari hasil yang menguntungkan bagi seluruh anggota kelompoknya. Sedangkan menurut Lie (2008) pembelajaran kooperatif dengan istilah pembelajaran gotong royong, yaitu system pembelajaran yang memberi kesempatan kepada peserta didik untuk bekerjasama dengan siswa lain dalam tugas-tugas yang terstruktur. Lebih jauh dikatakan, pembelajaran kooperatif hanya berjalan kalau sudah berbentuk suatu kelompok atau suatu tim yang di dalamnya siswa bekerja secara terarah untuk mencapai tujuan yang sudah ditentukan dengan jumlah anggota kelompok pada umumnya terdiri dari 4-6 orang saja.

Ibrahim dkk (2000) menyatakan bahwa pembelajaran kooperatif terdiri dari enam tahap seperti tabel berikut:

\section{Tabel 1}

Fase-fase Model Pembelajaran Kooperatif

\begin{tabular}{|l|l|}
\hline \multicolumn{1}{|c|}{ Fase } & \multicolumn{1}{|c|}{ Tingkah laku Guru } \\
\hline $\begin{array}{l}\text { 1. Menyampaikan tujuan } \\
\text { pembelajaran dan memotivasi } \\
\text { siswa }\end{array}$ & $\begin{array}{l}\text { Guru menyempaikan tujuan pembelajaran yang ingin } \\
\text { dicapai pada pembelajaran tersebut dan memotivasi siwa } \\
\text { belajar }\end{array}$ \\
\hline 2. Menyajikan informasi & Guru menyajikan informasi kepada siswa \\
\hline $\begin{array}{l}\text { 3. Mengorganisasikan siswa ke } \\
\text { dalam kelompok-kelompok } \\
\text { belajar }\end{array}$ & $\begin{array}{l}\text { Guru menjelaskan kepada siswa begaimana caranya } \\
\text { membentuk kelompok belajar dan membantu setiap } \\
\text { kelompok agar melakukan transisi/ perpindahan secara } \\
\text { efisien }\end{array}$ \\
\hline $\begin{array}{l}\text { 4. Membimbing kelompok bekerja } \\
\text { dan belajar }\end{array}$ & $\begin{array}{l}\text { Guru membimbing kelompok-kelompok belajar pada } \\
\text { saat mereka mengerjakan tugas mereka }\end{array}$ \\
\hline $\begin{array}{l}\text { 5. Evaluasi } \\
\text { Guru mengevaluasi hasil belajar tentang materi yang } \\
\text { telah dipelajari atau masing-masing kelompok } \\
\text { mempresentasikan hasil kerjanya }\end{array}$ \\
\hline 6. Memberikan penghargaan & $\begin{array}{l}\text { Guru mencari cara-cara untuk menghargai baik upaya } \\
\text { maupun hasil belajar individu dan kelompok }\end{array}$ \\
\hline
\end{tabular}

Bentuk penelitian yang dilakukan adalah Penelitian Tindakan Kelas (PTK) Kolaboratif.Menurut Arikunto (2008) bahwa penelitian tindakan kelas merupakan suatu pencermatan terhadap kegiatan belajar berupa sebuah tindakan yang sengaja dimunculkan dan terjadi dalam suatu kelas secara bersama.Tindakan tersebut diberikan oleh guru atau arahan dari guru yang dilakukan oleh siswa.Tindakan (action) dilakukan pada situasi alami dan ditujukan untuk memecahkan permasalahan.Tindakan yang dilakukan adalah Pembelajaran Kooperatif tipe STAD. 


\section{HASIL DAN PEMBAHASAN}

Slavin (1995) mengemukakan bahwa tipe STAD adalah suatu bentuk pembelajaran kooperatif yang sederhana. Dalam STAD, siswa dibentuk dalam kelompok-kelompok kecil yang beranggotakan 4 atau 5 orang dari berbagai kemampuan, gender, dan etnis. Dalam prakteknya guru menyajikan pelajaran dan kemudian siswa belajar dalam kelompok untuk memastikan bahwa setiap anggota kelompok telah menguasai materi. Penerapan pembelajaran kooperatif tipe STAD lebih mementingkan sikap dan proses dari pada prinsip, yaitu sikap dan proses pertisipasi dalam rangka mengembangkan potensi kognitif, afektif, dan psikomotor siswa.

Pembelajaran kooperatif tipe STAD diawali dengan guru menyajikan materi pembelajaran, dilanjutkan dengan siswa bekerja dalam kelompok yang terdiri dari empat sampai lima anggota. Selanjutnya setelah kegiatan kelompok dilakukan maka setiap siswa akan mengerjakan kuis/tes individual. Tetapi dalam mengerjakan kuis, setiap siswa harus bekerja secara individu.Setelah kuis, dilakukan perhitungan skor perkembangan individu dan diakhiri dengan tahap pemberian penghargaan bagi setiap kelompok yang berprestasi didasarkan pada rata-rata skor perkembangan siswa dalam tiap kelompok. Untuk lebih jelasnya langkah-langkah pembelajaran kooperatif tipe STAD adalah sebagai berikut:

\section{Penyajian Materi}

pada setiap penyajian materi siswa masih belum berada dalam kelompok-kelompok. Selain dari guru menyampaikan materipelajaran yang sudah disiapkan, guru perlu menyampaikan secara jelas tujuan pembelajaran khusus, memotivasi siswa, menjelaskan kisi-kisi yang perlu mereka lakukan ketika mereka bekerja atau belajar dalam kelompok, menginformasikan materi prasyarat dalam kaitan dengan materi yang akan dipelajari. Hal ini bertujuan untuk mengingatkan siswa tentang materi prasyarat dan menyiapkan diri untuk mengikuti dan memahami uraian materi pelajaran serta mampu berinteraksi dan berkomunikasi dalam kelompok.

\section{Kerja Kelompok}

Dalam setiap kelompok yang terdiri dari 4 atau 5 orang, tiap siswa diberikan lembar kerja (LKPD) berisikan tugas atau kegiatan yang harus dikerjakan berkaitan dengan materi pelajaran yang tadi guru jelaskan. Pada tahap kerja kelompok ini siswa akan berinteraksi dan saling membantu, mendiskusikan permasalahan/tugas yang harus mereka selesaikan. Akuntabilitas dari tiap anggota kelompok memastikan bahwa tiap individu harus terfokus pada aktivitas saling menolong dalam mempelajari materi yang diajarkan guru untuk memastikan bahwa setiap anggota siap untuk mengikuti kuis.Hasil kerja kelompok dituangkan dalam satu lembar kerja peserta didik dan dikumpulkan.Pada kerja kelompok, peranan guru adalah sebagai motivator dan fasilitator. 


\section{Kuis}

Sejauh mana keberhasilan siswa dalam belajar diketahui dengan diadakannya kuis oleh guru mengenai materi yang dibahas. Dalam mengerjakan kuis ini siswa harus bekerja secara individual sekalipun skor yang diperoleh nanti digunakan untuk menentukan keberhasilan kelompoknya. Kepada setiap individu, guru memberikan skor untuk nantinya digunakan dalam menentukan skor bersama bagi setiap kelompok.

Pada siklus pertama akan dilakukan tindakan yang sesuai dengan penerapan model pembelajaran kooperatif tipe STAD. Selanjutnya siklus kedua, tindakan yang akan dilakukan adalah berdasarkan hasil refleksi dari siklus pertama dan demikian seterusnya. Masing-masing komponen pada setiap siklus dalam penelitian ini berisikan:

\section{Perencanaan}

Pada tahap ini, hal-hal yang perlu dipersiapkan oleh peneliti adalah menyusun siklus penelitian, membuat 6 Rencana Pelaksanaan Pembelajaran (RPP), 6 Lembar Kegiatan Peserta Didik (LKPD), 6 tes formatif, mempersiapkan tes hasil belajar (2 ulangan harian), dan mempersiapkan lembar pengamatan.

\section{Pelaksanaan}

Pada pertemuan pertama peneliti langsung menerapkan model pembelajaran kooperatif tipe STAD. Adapun langkah-langkahnya adalah sebagai berikut:

\section{Pendahuluan}

1) Guru memperhatikan kesiapan siswa

2) Guru mengabsen siswa

3) Guru menyampaikan tujuan pembelajaran yang harus dicapai dalam pembelajaran

4) Guru memotivasi siswa

\section{Kegiatan Inti}

1) Guru meminta semua siswa untuk duduk dikelompok yang sudah ditentukan

2) Guru membagikan LKS

3) Siswa mendiskusikan pemecahan masaalah yang ada pada LKS yang diawali dengan mempelajari materi pokok sesuai dengan kemampuan masing-masing siswa dalam kelompok STAD. Disetiap kelompok terdapat seorang tutor yang mewakili guru untuk membantu teman-teman sekelompoknya yang memiliki kemampuan akademik rendah/lambat untuk menyelesaikan permasalahan yang diberikan.sehingga adanya system pembelajaran individudalam kelompok STAD.

4) Tutor yang ada disetiap kelompok ditunjuk oleh guru yang bersangkutan berdasarkan nilai ulangan harian pada pokok bahasan sebelumnya dan diberitahukan sebelum dimulainya kelompok STAD. 
5) Perwakilan dari salah satu kelompok menyajikan hasil kerja kelompoknya dan kelompok lainnya manggapi presentasi dan guru sebagai fasilitator motivator, dan mengkoordinir waktu.

\section{Penutup}

1) Guru melakukan Tanya jawab untuk mempermantap pemahaman siswa tentang materi yang telah dipelajari sekaligus memberikan penguatan-penguatan atas materi tersebut.

2) Guru membimbing siswa membuat rangkuman tentang materi pembelajaran yang baru dipelajarui

3) Kuis

\section{Pengamatan}

Tindakan diamati setiap kali pertemuan tentang aktivitas dan interaksi siswa dan guru pada penerapan pembelajaran kooperatif tipe STAD.Pengamat mengamati mulai dari kegiatan awal, kegiatan inti sampai kegiatan akhir, kemudian mendekripsikan secara rinci pada lembar pengamatan.

\section{Refleksi}

Mengkaji secara menyeluruh tindakan yang telah dilakukan berdasarkan data yang telah terkumpul, kemudian dilakukan evaluasi guna menyempurnakan tindakan. Jika terdapat masalah dari proses refleksi maka dilakukan pengkajian ulang melalui siklus berikutnya, sehingga permasalahan dapat diselesaikan. Kelemahan dan kekurangan dari tindakan diperbaiki pada siklus berikutnya.

\section{Hasil Penelitian}

\section{Hasil Belajar Siswa}

Hasil belajar siswa pada mata pelajaran matematika dengan menggunaklan model pembelajaran Kooeperatif Tipe Student Teams Achievemen Division (STAD) dalam penelitian ini dianalisis melalui beberapa aspek, daya serap siswa dan ketuntasan belajar siswa yang terdiri dari ketuntasan individu dan ketuntasan klasikal.

a. Daya Serap

Berdasarkan data pada lampiran 14 dan 15 diperoleh daya serap siswa pada siklus 1 dan siklus 2 sebagai hasil ulangan pada akhir setiap siklus tersebut. Berikut adalah daya serap siswa pada ulangan harian 1 siklus I. 
Tabel 2

Daya Serap Siswa pada Nilai Ulangan Harian 1 Siklus I

\begin{tabular}{|c|c|c|c|}
\hline No & Interval & Kategori & Daya Serap Siswa UH 1 Siklus I (\%) \\
\hline 1 & $80-100$ & Amat Baik & $7(27 \%)$ \\
\hline 2 & $70-79$ & Baik & $5(19 \%)$ \\
\hline 3 & $60-69$ & Cukup & $5(19 \%)$ \\
\hline 4 & $50-59$ & Kurang & $3(11 \%)$ \\
\hline 5 & $0-49$ & Amat Kurang & $6(23 \%)$ \\
\hline \multicolumn{3}{|c|}{ Jumlah Siswa } & 26 \\
\hline \multicolumn{3}{|c|}{ Rerata } & 68 \\
\hline \multicolumn{3}{|c|}{ Kategori } & Cukup \\
\hline
\end{tabular}

Berdasarkan tabel 2, dapat dilihat rerata daya serap siswa adalah 68 yang dikategorikan cukup. Mayoritas siswa mempunyai daya serap dengan kategori cukup ke atas yaitu dari interval 60 - 69 dan 80 - 100, yakni sejumlah 17 orang $(65,39 \%)$ dan ada siswa yang memperoleh skor antara 0 49 sebanyak 6 orang $(23 \%)$. Berikut adalah laporan daya serap siswa pada ulangan harian 2 siklus II:

\section{Tabel 3}

Daya Serap Siswa pada Nilai Ulangan Harian 2 Siklus II

\begin{tabular}{|c|c|c|c|}
\hline No & Interval & Kategori & Daya Serap Siswa UH 2 Siklus II (\%) \\
\hline 1 & $80-100$ & Amat Baik & $9(34,6 \%)$ \\
\hline 2 & $70-79$ & Baik & $9(34,6 \%)$ \\
\hline 3 & $60-69$ & Cukup & $3(11,5 \%)$ \\
\hline 4 & $50-59$ & Kurang & $3(11,5 \%)$ \\
\hline 5 & $0-49$ & Amat Kurang & $2(7,7 \%)$ \\
\hline \multicolumn{3}{|c|}{ Jumlah Siswa } & 26 \\
\hline \multicolumn{3}{|c|}{ Rerata } & 73.98 \\
\hline \multicolumn{3}{|c|}{ Kategori } & Baik \\
\hline
\end{tabular}

Berdasarkan tabel 3 dapat dilihat rerata daya serap siswa adalah 73,98 yang dikategorikan baik. Mayoritas siswa mempunyai daya serap antara interval $70-100$, yakni sejumlah 18 orang $(69,2 \%)$ dan masih ada siswa yang memperoleh skor antara $0-49$ sebanyak 2 orang $(7,7 \%)$. 
b. Ketuntasan Belajar

Berdasarkan data pada lampiran 7 dan 9 diperoleh ketuntasan belajar siswa pada siklus I dan II yang didapat dari hasil ulangan harian dan laporan daya serap siswa. Berikut adalah laporan ketuntasan belajar siswa pada ulangan harian 1 siklus I:

Tabel 4

Ketuntasan Belajar Siswa dengan Menggunakan Model Pembelajaran (STAD)

\begin{tabular}{|c|l|c|c|}
\hline \multirow{2}{*}{ Nilai } & \multicolumn{3}{|c|}{ Ketuntasan Belajar Siswa } \\
\cline { 2 - 4 } & \multicolumn{2}{|c|}{ Individu } & Klasikal \\
\cline { 2 - 3 } & Tuntas (\%) & Tidak Tuntas (\%) \\
\hline UH 1 Siklus I & $12(46 \%)$ & $14(54 \%)$ & $46 \%$ \\
\hline UH 2 Suiklus II & $18(69 \%)$ & $8(31 \%)$ & $69 \%$ \\
\hline
\end{tabular}

Tabel 4 menunjukkan bahwa ketuntasan belajar siswa secara individu maupun klasikal meningkat. Secara umum atau klasikal, ketuntasan belajar siswa meningkat dari ulangan harian 1 siklus 1 sejumlah $46 \%$ keulangan harian 2 siklus 2 sejumlah $69 \%$.

Aktivitas Siswa

Berdasarkan lampiran 10 terlihat jelas bahwa aktivitas siswa untuk setiap indikator pengamatan meningkat dari siklus 1 ke siklus 2 . Seperti yang terlihat pada tabel 5 .

\section{Tabel 5}

\section{Aktivitas Siswa}

\begin{tabular}{|l|c|c|c|c|c|c|c|}
\hline \multirow{2}{*}{ No } & \multicolumn{7}{|c|}{ Indikator Butir Aktivitas Siswa } \\
\cline { 2 - 8 } & 1 & 2 & 3 & 4 & 5 & 6 & 7 \\
\hline Siklus I & 83,3 & $58,3 \%$ & $66,7 \%$ & $75,0 \%$ & $66,7 \%$ & $66,7 \%$ & $75,0 \%$ \\
& $\%$ & & & & & & \\
\hline $\begin{array}{l}\text { Siklus } \\
\text { II }\end{array}$ & $100 \%$ & $91,7 \%$ & $91,7 \%$ & $75,0 \%$ & $66,7 \%$ & $75 \%$ & $91,7 \%$ \\
\hline
\end{tabular}

\section{Keterangan:}

Indikator butir aktivitas siswa:

a. Siswa didik dalam kelompok yang telah ditentukan

b. Siswa berdiskusi dalam kelompoknya masing-masing

c. Siswa mengerjakan tugas yang diberikan guru

d. Salah seorang wakil kelompok mempresentasikan hasil kerja kelompoknya

e. Siswa yang lain menyimak prentasi kelompok lain 
f. Siswa menanggapi presentasi temannya

g. Siswa membuat kesimpulan dan rangkuman hasil pembelajaran

Tabel 5. menunjukkan adanya perubahan positif yang terjadi pada aktivitas siswa selama proses pembelajaran dari siklus 1 ke siklus 2 pada masing-masing indikator butir aktivitasn siswa yang diamati oleh observer (pengamat).

Berdasarkan hasil analisis data di atas yang meliputi hasil belajar siswa (daya serap dan ketuntasan belajar) dan aktivitas guru dan siswa dalam pelaksanaan tindakan yaitu penerapan model pembelajaran kooperatif tipe STAD pada proses pembelajaran metematika di kelas XI IPA SMAN 1 Bangkinang, didapatkan informasi bahwa hasil belajar siswa meningkat, seperti tergambar dalam tabel 6 berikut.

Tabel 6

Hasil Belajar Siswa Menggunakan Model Pembelajaran Kooperatif Tipe STAD

\begin{tabular}{|c|c|c|c|}
\hline Tahap & $\begin{array}{c}\text { Rerata Daya } \\
\text { Serap Siswa }\end{array}$ & $\begin{array}{c}\text { Ketuntasan Belajar } \\
\text { Siswa }\end{array}$ & $\begin{array}{c}\text { Ketuntasan Belajar siswa } \\
\text { secara Klasikal }\end{array}$ \\
\hline Siklus 1 & 67,55 & $12(46 \%)$ & $46 \%$ \\
\hline Siklus 2 & 73,98 & $18(69 \%)$ & $69 \%$ \\
\hline
\end{tabular}

Berdasarkan tabel 6 diketahui bahwa hasil belajar siswa meningkat dari siklus 1 ke siklus 2 . Daya serap siswa erat kaitannya dengan ketuntasan belajar siswa, karena jika daya serap siswa sudah baik dan siswa mendapat nilai baik, secara otomatis siswa juga akan tuntas atau memperoleh nilai $\geq$ 70 (KKM). Dalam penelitian ini, daya serap siswa meningkat, yakni dari rerata 67,55 pada siklus 1 menjadi 73,98 pada siklus 2. Peningkatan ini juga terjadi pada ketuntasan belajar secara klasikal, yaitu dari 12 orang siswa (46\%) pada siklus 1 menjadi 18 orang (69\%) pada siklus 2. Ketuntasan belajar klasikal dinyatakan tuntas jika $\geq 85 \%$ siswa telah menguasai materi pelajaran. Jadi dapat dikatakan bahwa pada siklus kedua, siswa belum dapat dinyatakan tuntas secara klasikal, dikarenakan ketuntasan secara klasikal masih $<85 \%$.

Hasil yang didapat ini merupakan efek langsung dari aktivitas guru dan siswa pada proses pembelajaran dengan menggunakan model pembelajaran Kooperatif Tipe Student Teams Achievemen Division (STAD) yang telah dilakukan. Dari hasil pengamatan (observer) diketahui bahwa adanya perubahan positif pada siswa dalam memahami materi pelajaran melalui penggunaan model pembelajaran kooperatif tipe STAD dari siklus 1 ke siklus 2. Pada siklus 1, hasil siswa secara umum belum memuaskan dikarenakan belum semua siswa mampu memahami materi pelajaran dengan baik. Siswa belum terbiasa bekerja secara kooperatif atau berdiskusi dalam kelompok dalam memahami materi yang diajarkan. Siswa belum mampu menjawab pertanyaan yang diberikan guru terkait materi yang diberikan dan tentu saja tidak siap untuk melaporkan hasil diskusi kelompoknya tersebut. Pada siklus 2 aktivitas siswa sudah menunjukkan perubahan yang signifikan jika dibandingkan dengan 
siklus 1. Pada siklus ini, siswa sudah mulai nyaman belajar dan berdiskusi dalam kelompoknya masing-masing. Siswa sudah cukup baik dalam memahami materi ajar dan menjawab pertanyaan guru serta mempresentasikannya di depan kelas sebagai efek baik dari diskusi kelompok.

Berdasarkan data yang diperoleh seperti di atas, terlihat bahwa terjadi peningkatan jumlah peserta didik yang mencapai KKM dari hasil ulangan harian I ke hasil ulangan harian II. Disebabkan hasil belajar siswa setelah tindakan lebih baik dari hasil sebelum tindakan, maka dapat dikatakan tindakan sudah berhasil. Jika keberhasilan tindakan pada siklus I dibandingkan dengan hipotesis tindakan yang pertama maka dapat disimpulkan bahwa hasil penelitian ini mendukung hipotesis tindakan yang pertama. Sehingga hipotesis tindakan yang pertama, yaitu "hasil belajar metematika dapat meningkat melalui penerapan model pembelajaran Tipe STAD di kelas XI IPA SMA Negeri 1 Bangkinang tahun pelajaran 2016/2017 pada Kompetensi Dasar 1.4. Meggunakan aturan perkalian, permutasi, dan kombinasi dalam pemecahan masalah." dapat diterima kebenarannya. Berdasarkan hasil analisis keberhasilan tindakan juga diketahui pada siklus II dikatakan berhasil. Jika keberhasilan tindakan pada siklus II dibandingkan dengan hipotesis tindakan yang kedua maka dapat disimpulkan bahwa hasil penelitian ini mendukung hipotesis tindakan kedua. Sehingga hipotesis tindakan yang kedua, yaitu "hasil belajar mtematika dapat meningkat melalui penerapan model pembelajaran Tipe STAD di kelas XI IPA SMA Negeri 1 Bangkinang tahun pelajaran 2016/2017 pada Kompetensi Dasar 1.5. Menentukan ruang sampel suatu percobaan; dan 1.6. Menentukan peluang suatu kejadian dan penafsirannya" juga dapat diterima kebenarannya.

\section{KESIMPULAN}

Berdasarkan data dan analisis penelitian yang sudah dijabarkan, terlihat bahwa adanya peningkatan hasil belajar siswa dan aktivitas siswa dari siklus 1 ke siklus 2 setelah dilakukan pembelajaran dengan menggunakan model pembelajaran kooperatif tipe STAD. Dari hasil belajar siswa, dapat dilihat bahwa daya serap siswa meningkat dari 67,55 (siklus 1) menjadi 73,98 (siklus 2), sedangkan ketuntasan siswa meningkat dari 46\% (siklus 1) menjadi 69\% (siklus 2). Dari segi aktivitas siswa, pengamat menilai bahwa juga ada peningkatan dari siklus 1 ke siklus 2 untuk tiap-tiap indikator penilaian aktivitas siswa. Jadi dapat disimpulkan bahwa, penerapan model pembelajaran kooperatif tipe STAD dapat meningkatkan hasil belajar siswa pada mata pelajaran matematika di kelas XI IPA SMAN 1 Bangkinang.

\section{DAFTAR PUSTAKA}

Arikunto, Suharsimi. 2008. 2002. Dasar-dasar Evaluasi Pendidikan. Jakarta : PT. Rineka Cipta 2006. Penelitian Tindakan Kelas. Jakarta : Bumi Aksara

Depdiknas, 2006. Peraturan Mentri Pendidikan Nasional Nomor 22 Tahun 2006. Tentang Standar Isi.

Depdiknas. 2006. Kurikulum SMA. Jakarta : Depdiknas 
Dimyati \& Mudjiono, 2006. Belajar dan Pembelajaran. Jakarta: Rineka Cipta

Elprida, Eka. http//ekaelprida.blogspot.co.id/p/blog-page_4778.html, online diakses tanggal 27 Februari 2017

Hudoyo, Herman, Drs, M.Ed, 1979, Pengembangan kurikulum Matematika dan pelaksanaannya di depan kelas. Surabaya : Usaha Nasional

Ibrahim, Muslimin, dkk. 2002. Pembelajaran Kooperatif. Surabaya : University Press.

Lie, Anita. 20082. Cooperative Learning : Mempraktikkan Cooperative Learning di Ruang-ruang Kelas. Jakarta : PT. Gramedia

Slavin, Robert E, 1996. Psikologi Pendidikan teori dan praktek,(edisi kedelapan), Jakarta :Indeks

Slameto. 2003. Belajar dan Faktor-faktor yang Mempengaruhinya. Jakarta: Rineka Cipta

Sugiyono. 2006. Metode Penelitian Pendidikan. Bandung: Alfabeta

Taufik, M.D., 2012. http://mdtaufiq.blokspot.co.id/2012/12/hasil-belajar-matematika.htlm. Online. Diakses tanggal 23 Februari 2017

Sudjana, Nana, 2009. Penilaian Hasil Proses Belajar Mengajar. Bandung: PT. Remaja Rosdakarya 